\section{SOBRE UM FIM EM ANÁLISE}

\section{Psicanálise interminável ou com fim possivel?, de Theodor Lowenkron. Rio de Janeiro: Imago, 2007, 80 p.}

\section{Irene Gondim Grether \\ Psicóloga e psicanalista, mestre em Teoria Psicanalítica pela UFRJ e professora do Instituto de Psicologia e Psicanálise da Universidade Santa Úrsula.}

\section{Alzira Costa de Oliveira \\ Psicóloga e psicanalista, mestre em Teoria Psicanalítica pela UFRJ, pós-graduada em Docência do Ensino Superior na Unicarioca e professora da Face-Bennett de Psicologia e Psicopatologia da Terceira Idade.}

Trata-se de uma obra que oferece uma contribuição decisiva para a transmissão da experiência psicanalítica. Tomando como base a narrativa clínica, o autor — um dos principais especialistas em psicanálise de nosso meio - utiliza-se, para cumprir seu objetivo, do recurso da transcrição de parte das sessões psicanalíticas realizadas com um dos seus pacientes durante seis anos. Seu estilo é preciso, num texto que por si só torna-se explicativo, e reúne os aspectos essenciais das consultas, permeados pela teoria e demonstrações práticas da mesma, o que torna acessível para o leitor, psicanalista ou não, conceitos bastante complexos, sem ser simplista.

Assim, ao apresentar o relato detalhado e envolvente do caso desse paciente, vai além do propósito terapêutico, no sentido de que se volta para a tríplice perspectiva da terapia, da investigação e do ensino, com base em sua sólida experiência como professor, pesquisador e clínico.

É importante ressaltar que tal obra é oferecida a nós por Theodor Lowenkron, um autor com experiência e competência para produzir um trabalho de significativa magnitude, uma vez que é, dentre muitos títulos, mestre e doutor em Psiquiatria pela UFRJ.

Inicia seu trabalho retomando um questionamento crucial para o campo da psicanálise, enquanto sustenta uma discussão importante sobre o fim da análise, em um contexto atual em que as análises intermináveis se configuram quase como uma lei.

Do ponto de vista clínico, trata-se de uma narrativa clínica bastante detalhada. Também por esse motivo é texto paradigmático, uma vez que essa modalidade de publicação cada vez mais fica escassa na comunidade analítica da atualidade. Isto, em oposição ao passado em que tais publicações eram costumeiras. Então, mais um motivo para se saudar a obra de Lowenkron como um resgate precioso na transmissão do campo teórico e clínico da psicanálise.

Seu relato ainda se faz sob a forma de um texto articulado a outras contribuições teóricas nesse campo, por meio de distintos olhares científicos, aproveitando-se assim da técnica da atenção flutuante, sob a forma de uma teoria flutuante proposta por ele, como a contrapartida do pesquisador analista; ou seja, busca enriquecer sua reflexão sobre o material clínico com autores que melhor possam contribuir para 
o entendimento das diferentes questões. Assim, autores como Winnicott, da escola inglesa e outros de origem francesa e norte-americana, são citados na abordagem teórica em diferentes etapas do trabalho. Dentre esses autores diferenciados, identifica-se no texto mais as semelhanças entre eles do que suas diferenças, quando o autor sempre oferece um gancho teórico apresentando assim uma postura voltada para o campo clínico, com enfoque para o processo psicanalítico e sua eficácia terapêutica.

Também somos convidados a valernos do uso da idéia da teoria flutuante em nossa clínica e também a acrescentar, se possível, outros aportes teóricos no exercício criativo de sua leitura.

O livro não esgota aí suas possibilidades já que reflete sobre a pesquisa em psicanálise, quando tal modalidade de prática teórica se torna cada vez mais rarefeita na comunidade psicanalítica. Mais uma vez o autor resgata a tradição freudiana na qual a experiência psicanalítica sempre serviu como fonte permanente da teorização em psicanálise.

Ao final, o autor apresenta suas considerações e conclusões. Enfatiza a importância do referencial teórico utilizado e ressalta ainda sua teoria flutuante, que torna essa obra uma demonstração viva que exemplifica e por isso auxilia no processo de esclarecer e habilitar o profissional de saúde no exercício da psicoterapia e, ao mesmo tempo, serve de estímulo e ajuda no enfrentamento de possíveis resistências, bem como no encorajamento para um estudo mais aprofundado dos conceitos fundamentais da psicanálise - e, em especial, o término da análise.

Considera que, embora Freud tenha marcado em sua teoria e prática a importância da investigação e da pesquisa, muitos de seus seguidores desconsideram que esse método se faça tanto na teoria quanto na prática. O professor Lowenkron vem reforçar deste modo que se revise essa definição da psicanálise para que ela possa continuar a considerar e estimular as pesquisas para o progresso desse saber no campo da saúde mental.

Referindo-se especificamente à avaliação da pesquisa clínica que deu origem ao livro, retoma as questões iniciais do estudo. Assim é que, em suas próprias palavras, ao decidir nomear a tese Psicanálise interminável ou com fim possivel?, Lowenkron enfatiza o limite para o tratamento psicanalítico. Afirma que o objetivo da análise não é decifrar todas as peculiaridades do caráter humano em benefício de uma "normalidade", também não se trata de exigir que a pessoa que foi completamente analisada esteja isenta das paixões ou de novos conflitos internos. Sendo assim, embora a análise tenha sua contingência intrinsecamente interminável e, sendo a experiência infinita para cada paciente já que se impõe o interminável desejo —isso não implica que a análise não deva ter concretamente um fim.

Para o principiante, os fatos relatados neste contexto científico e ao mesmo tempo numa forma literária — similar ao modelo que Freud utilizava em seus artigos sobre casos clínicos - possibilitam a oportunidade de acompanhar suas atividades psicoterápicas, nesta obra especificamente psicanalítica. Ao expor com generosidade sua prática, também nos é franqueado o espaço ético e clínico vivido tanto por Lowenkron como por seu paciente. Tal conduta acaba funcionando também como uma espécie de sala de consulta do psicanalista e sala de aula do professor e nos torna testemunhas de seu trabalho como pesquisador.

O livro constitui-se, assim, num exemplar único e indispensável para mé- 
dicos, psicólogos, psiquiatras, psicanalistas, pesquisadores, demais trabalhadores de saúde mental e alunos de graduação das ciências humanas.

Recebida em 13/10/2007. Aprovada em 14/11/2007.

Irene Gondim Grether gigrether@yahoo.com.br Alzira Costa de Oliveira costalzira@hotmail.com 